\title{
Determinants of audit fees for Portugal and Spain
}

\author{
Determinantes de los honorarios por auditoría para Portugal y España
}

\author{
Ana Sofía Valente Cunha Silva*, Helena Coelho Inácio, \\ Elisabete F. Simões Vieira
}

Universidade de Aveiro, Portugal

Received November 11, 2018; accepted October 22, 2019

Available online November 11, 2019

\begin{abstract}
This paper intends to analyze the determinants of audit fees in Portugal and Spain at a time when the audit profession has felt increasingly strong pressures on its ethical, independence and quality of professional attitude, showing that audit fees behave differently in these two countries. The liberalization of audit services' fees in Portugal, with the elimination in 2005 of the minimum audit fees table based on the audited company size, arouses the interest in perceiving the factors that determine audit fees. In Spain, the various financial scandals have placed audit fees in the main focus. These countries, which form the Iberian Peninsula, have a strongly related economic and cultural history, having also joined the European Union on the same date. In addition, audit fees have not been much studied in these countries, so it is important to perceive their behavior by comparing results. The results indicate that, in Spain, audit fees are determined mainly by the size, complexity and risk of the audited company. It was also found in Spain that the big four companies charge higher fees and companies that change their audit firm pay lower fees in the year of rotation. In Portugal, the size of the audited company was considered the only factor contributing to the determination of audit fees. The analysis includes a sample of 39 listed companies in Portugal and 104 companies listed in Spain for the period of 2013 to 2015 using the ordinary least squares.

\footnotetext{
"Corresponding author.

E-mail address: anasilva@ua.pt (A.S.Valente Cunha Silva).

Peer Review under the responsibility of Universidad Nacional Autónoma de México.

http://dx.doi.org/10.22201/fca.24488410e.2020.2039

0186- 1042/@2019 Universidad Nacional Autónoma de México, Facultad de Contaduría y Administración. This is an open access article under the CC BY-NC-SA (https://creativecommons.org/licenses/by-nc-sa/4.0/)
} 


\section{A. S. Valente Cunha Silva, et al. / Contaduría y Administración 65(4), 2020, 1-24}

http://dx.doi.org/10.22201/fca.24488410e.2020.2039

Códigos JEL: M41, M42, M48, M49

Keywords: Auditing; Fees; Independence; Portugal; Spain

\section{Resumen}

Este artículo tiene como intención analizar los determinantes de los honorarios por auditoria en Portugal y España en un período en el que esta profesión experimenta fuertes y crecientes presiones sobre la ética, independencia y calidad de su actitud profesional, mostrando que dichos honorarios se comportan de manera diferente en estos dos países. La liberalización de los honarios por servicios de auditoría en Portugal, al eliminar en 2005 la tabla de honorarios mínimos basada en el tamaño de la empresa auditada, despierta el interés en detectar los factores que los determinan. en En España los diversos escándalos financieros han puesto esos honorarios en el foco principal. Estos países, que forman la península ibérica, tienen una economía e historia cultural fuertemente relacionadas, habiéndose incorporado a la Unión Europea en la misma fecha. Adicionalmente, los honorarios por auditoría no se han estudiado mucho en estos países, por lo que es importante detectar sus comportamientos y comparar los resultados. Los resultados indican que en España están determinados principalmente pro el tamaño, complejidad y riesgo de la empresa auditada. También se encontró que en ese país las cuatro firmas auditoras más grandes cobran honorarios más altos y que las émpresas que cambian de firma auditora pagan honorarios más bajos durante el año del cambio. En Portugal el tamaño de la empresa auditada fue el único factor que contribuye a la determinación de los honorarios. El análisis, usando mínimos cuadrados ordinarios, incluye una muestra de 39 empresas listadas en el mercado de valores de Portugal y 104 en el de España de 2013 a 2015.

Códigos JEL: M41, M42, M48, M49

Palabras clave: Auditoría; Honorarios; Independencia; Portugal; España

\section{Introduction}

The concern about the reliability of financial information has been growing over the last years. As a result of the growing importance of financial markets for the world economy and the financial scandals over the years, regulators have been required to take measures to increase information reliability. Because of this, stakeholders, in general, have become more demanding. In this context, the auditing profession as an activity whose main function is to contribute to the reliability of information is experiencing a strong pressure on its ethical position, independence and quality. Audit fees can jeopardize the auditor's independence to the extent that if they are set high they can indicate corruption between client and auditor, but if too low 
it can also be indicative that the auditor did not take the necessary efforts to issue a proper opinion. Collier and Gregory (1996) mentioned that the ability of auditors to identify failures in accountability of audited companies depends on their independence to determine the appropriate audit techniques, as well as the extent of their application. Auditor's work should not be limited to the amount of their fees but be based on a judgment of what is necessary to achieve an adequate opinion (Collier \& Gregory, 1996).

Literature has highlighted several determining factors of audit fees, such as the size, complexity and risk of audited companies, the audit firm size, the amount of non-audit fees, and to a smaller extent, focused on the concern related to earnings management by audited companies, so we decided to analyze the influence of these factors on audit fees in Portugal and Spain. These two countries that form the Iberian Peninsula have a strongly related economic and cultural history, having also joined the European Union on the same date. In addition, audit fees have not been much studied in these countries, so it is important to understand their behavior by comparing results.

Unlike the Anglo-Saxon countries such as the U.S.A and the U.K, listed companies in Portugal and Spain are characterized by having a concentrated ownership structure, which can lead to earnings management activities.

Concerning the audit services market, these two countries are also characterized by the preeminence of the big four ${ }^{1}$, however, there are some particularities in the law that distinguish them, especially in Portugal, where until 2005 external audit fees were regulated by a threshold based on the audited company size standards. From 1 January 2005, the minimum fees were eliminated in order to allow the liberalization of audit services. On the other hand, Spain has been subject of a series of financial scandals that have affected the country, in particular Pescanova and Let's Gowex, S.A. cases, which put the audit fees in the main focus.

This study is organized as follows. Section two presents the literature review and formulates research hypotheses. The third section presents the methodology, describing the sample, the models and variables. In the fourth section the results are presented and analyzed. Finally, we submit the conclusions, limitations and suggestions for future research.

\footnotetext{
${ }^{1}$ Initially, the group of companies considered as leaders consisted of eight large audit firms, known by big eight. Over the years, the number of companies belonging to this group has been reduced due to merger processes, being reduced to five companies, and after the financial scandal involving Enron and Arthur Anderson, they became four (big four). Currently the big four are PricewaterhouseCoopers, KPMG, Ernest \& Young and Delloite.
} 


\section{Literature Review}

Size

Audited company size has been pointed by literature as one of the main factors influencing the determination of external audit fees. In general, large companies have more types and a higher volume of transactions that require, consequently, further analysis and verification by the auditor, which will be reflected in the fees charged. Joshi and Al-Bastaki (2000) argued that the audit fees charged are higher for larger companies, as auditors spend more time and effort in the analysis of its client's operations. Naser and Nuseibeh (2007) also mentioned that "large firms are more likely to be subject to public scrutiny, higher agency and political costs and are therefore a higher risk for the auditor" (p. 243).

Gerrard, Houghton, and Woodliff (1994) found, through a study in Australia, that audit market is very competitive, so auditors use resources that allow them to achieve economies of scale, despite the large size and complexity of the audited company. The increased cost of audit is not, therefore that linear because although fees are high in large and complex companies, currently external auditors have a set of tools that allow them to reduce to a certain level the final costs (e.g. the use of efficient and less costly mechanisms, such as, analytical procedures). Despite auditor's efforts can be reduced with such tools, several authors have found a positive association between the size of the audited company and external audit fees (Gul, Chen, \& Tsui, 2003, in Australia; Hassan \& Naser, 2013, in the United Arab Emirates; Joshi \& AL-Bastaki, 2000, in Bahrain; Karim \& Hasan 2012, in Bangladesh; Kimeli, 2016, in Kenya; Naser and Nuseibeh, 2007, in Jordan; Palmrose, 1986, in the U.S.A; Simunic, 1980, in the U.S.A; Urhoghide \& Izedonmi, 2015, in Nigeria). Suwaidan and Qasim (2010) also found in Jordan that the size of audited company is the most contributing factor of external audit fees oscillations.

Considering this, we developed the following research hypothesis:

$\mathrm{H}_{1}$ : There is a positive association between the size of the audited company and external audit fees.

\section{Complexity}

The complexity of the audited company has also been identified as one of the determining factors of external audit fees, to the extent that companies with greater complexity require a greater audit work, which will be reflect in their fees. Several authors found a positive as- 
sociation between the complexity of the audited company and external audit fees (Carcello, Hermanson, Neal, \& Riley, 2002, in the U.S.A; Gul et al, 2003, in Australia; Hassan \& Naser, 2013, in the United Arab Emirates; Joshi \& AL-Bastaki, 2000, in Bahrain; Kimeli, 2016, in Kenya; Simunic, 1980, in the U.S.A; Urhoghide \& Izedonmi, 2015, in Nigeria). Usually, the complexity of the audited company is associated with diversity and difficulty of its operations, requiring a more carefully supervision from the auditor. For example, companies with a larger number of subsidiaries or subsidiaries located abroad are exposed to a greater complexity. Al-Shammari, Al-Yaquot and Al-Hussaini (2008) also observed that a better understanding of the business environment, as well as a more intensive analysis of its assets when the environment surrounding the company is itself very complex is required from the auditor, which will lead to an increase in their fees.

Based on the literature we formulated, therefore, the following research hypothesis: $\mathrm{H}_{2}$ : There is a positive association between the complexity of the audited company and external audit fees.

\section{Audit Firm}

Some companies stand out in the audit sector as industry leaders. Given the importance these companies have in the market, the literature has focused on its audit fees influence.

In general authors have found a positive association between external audit fees and those that are considered the largest auditing firms worldwide (Campa, 2013, in the United Kingdom; Caneghem, 2010, in Belgium; Ho \& Hutchinson, 2010, in Hong Kong; Kimeli, 2016, in Kenya; UlHaq \& Leghari, 2015, in Pakistan). These results could mean that large companies perform audits with a greater quality when compared to other companies in the sector, which will result in higher audit costs and consequently in higher audit fees or could mean that large companies monopolize the audit market and charge fees for its brand (Simunic, 1980).

Campa (2013) found in the United Kingdom that the big four charge their clients an audit premium that is, an additional amount of fees because they belong to the big four, which didn't result in an increase of audit quality, measured by earnings management, accounting conservatism and the relevance of earnings value. In turn, Caneghem (2010) found, for listed companies in Belgium, the existence of an audit fee premium charged by the big four when using the traditional model of audit fees that was the model initially created by Simunic (1980). However, when using coefficients ranging between the big four and non-big four, Caneghem (2010) concluded that these two groups of companies use different criteria in the determination of their fees. Kimeli (2016), through a study conducted in Kenya, argued 
that the big four use their financial resources to ensure the quality of its audits by investing in appropriate training programs and staff with a high level of qualification. According to UlHaq and Leghari (2015), in Pakistan, the big four are seen as having a higher quality than the non-big four, which makes these companies charge for an audit premium.

Based on the literature review, we developed the following research hypothesis:

$\mathrm{H}_{3}$ : The big four charge higher audit fees.

Risk

Audit risk is the probability of the auditor issuing an inappropriate opinion on the financial statements of the audited company. Audit risk includes (i) the risk of existence of material misstatements in the financial statements of the audited company (inherent risk and control risk) and (ii) the risk of the auditor not detecting a material misstatement (detection risk). Thus, the auditor assesses the risk of material misstatement in the financial statements of the audited company, through the knowledge (understanding) obtained from the environment surrounding the company, including its internal control system, in order to provide a basis for the design and implementation of responses to the assessed risks of material misstatement (International Accounting Standard [ISA] 315, §3). It is on this basis that the auditor determines the nature, timing and extent of procedures to be used during the audit.

The risk is, therefore, an important factor to be considered by the auditor, as a bad assessment of the business risk can jeopardize the entire audit and may lead to legal actions against the auditor, which can ruin his reputation in the market. Such losses for the auditor may result from an incorrect analysis of the client's business risk or from other facts such as a failure in the detection of material errors in the financial statements (Pong \& Whittington, 1994).

However, the analysis between risk and audit fees is seen by many authors as very complex, since risk can be measured by different components. Considering the difficulty in measuring the risk associated with company control and its business (Pong \& Whittington, 1994) literature addresses mainly the financial risk. A high financial risk may result in material financial errors that are more difficult to detect (Kreutzfeldt \& Wallace, 1986), as well as legal proceedings and financial losses in case of bankruptcy of the audited company (Gonthier-Besacier \& Schatt, 2007). In this latter case it is present the auditor's business risk that is traditionally defined as "the probability that an auditor will suffer a loss because of a client relationship. Such loss may arise e.g. from litigation, sanctions imposed by regulatory bodies, impaired reputation capital or failure to collect fees" (Niemi, 2002, p. 38). Pratt and Stice (1994), through a study in the United States, concluded that the financial condition of 
the audited company is the first element to be taken into account when assessing litigation risk because auditors associate a weak financial position to a higher level of risk, which leads to a larger collection of audit proof and, consequently, higher fees.

Some authors didn't find, however, a significant association between financial risk and audit fees (Hassan \& Naser, 2013, in the United Arab Emirates; UlHaq \& Leghari, 2015, in Pakistan). According to UlHaq and Leghari (2015) the risk should not be ignored by auditors because it can result in serious implications to the reputation of the audit firm, aggravated by the weak legal system of Pakistan.

Thus, if the company has a high risk, the auditor must incur on a greater effort to decrease the likelihood of undetected material misstatements and, therefore, moderate the risk of issue a wrong opinion. So, it is expected that external auditors include this additional effort on their fees or charge a risk premium (Pratt \& Stice, 1994).

We, therefore, formulated the following research hypothesis:

$\mathrm{H}_{4}$ : There is a positive association between risk and external audit fees.

\section{Non-audit Fees}

The literature has discussed in an equal way the association between external audit fees and the amount of other services charged by auditors, often known as non-audit fees.

Some authors argue that when providing audit services and other services simultaneously (e.g. consultancy services), the auditor carries knowledge from one area to another, resulting in an increase in audit fees (Caneghem, 2010, in Belgium; Mayoral \& Segura, 2007, in Spain; Simunic, 1980, in the U.S.A; Thinggaard \& Kiertzner, 2008, in Denmark).

Thinggaard and Kiertzner (2008) found that non-audit fees are the most significant factor in determining audit fees in Denmark. According to the authors, the auditors use audit services as a way to get from their clients requests to provide other services that will not result in a discount price on audit, but rather in a greater effort by auditors.

Contrary to expectations, some authors have not found a significant association between external audit fees and non-audit fees (Adelopo, 2009, in the UK; Dunmore \& Shao, 2006, in New Zealand; Sharma \& Sidhu, 2001, in Australia). Dunmore and Shao (2006), for example, justified these results stating that "perhaps the market for audit services in New Zealand is not sufficiently competitive to compel auditors to discount their audit fees by the expected profits on 'tied' non-audit services" (p.43). However, Felix, Gramling and Maletta (2001) by analyzing the market for U.S.A, verified a negative and significant association between audit fees and non-audit fees. According to the authors, these results can be justified by the 


\section{A. S. Valente Cunha Silva, et al. / Contaduría y Administración 65(4), 2020, 1-24}

http://dx.doi.org/10.22201/fca.24488410e.2020.2039

increased competition in the audit market, that motivate auditors to provide a reduction in the value of audit services to enable them to get more profitable consulting business.

We expect, therefore, a significant association between non-audit fees and external audit fees, although, we cannot a priori predict the direction this association will take:

$\mathrm{H}_{5}$ : There is a significant association between non-audit fees and external audit fees.

\section{Earnings Management}

Another factor that has become increasingly important in determining external audit fees is the risk of earnings management that has been analyzed in the literature through accruals.

By analyzing the literature, it was found that the use of accruals as a way of earnings management is a common practice between managers because accruals result from estimates easily manipulated. According to Gul et al. (2003) accruals may be opportunistically manipulated by managers to camouflage poor results or postpone an unusual part of current earnings for future years.

Certain authors such as Heninger (2001) chose to measure earning management through discretionary accruals, also called abnormal accruals, that are those that don't result from the normal course of business activity. According to Kaplan (1985), earnings management doesn't usually result from normal accruals as they arise from the normal activity of the company. Balsam (1998) also noted that discretionary accruals include a lot of estimates and transactions which effect in total accounting income is not easily estimated and disclosed.

Earnings management can be a result of several incentives, ranging from company's disclosure of information to the satisfaction of their own interests. According to Krishnan (2003), managers can use accruals to communicate internal information of the company and increase the earnings' ability to reflect the economic value of the company, but can also be used on a timely way, distorting the information produced through the reported accruals.

It is expected, therefore, that large amounts of discretionary accruals lead to a greater risk for external auditors, that is, the risk of validating accruals that may not be realized, so that the auditor's effort will be greater and consequently their fees (Alali, 2011, in the U.S.A; Gu $\& \mathrm{Hu}, 2015$, used a sample of listed Japanese companies in the U.S.A; Gul et al., 2003, in Australia). According to $\mathrm{Gu}$ and $\mathrm{Hu}$ (2015), it is required to the auditor more work to review and supervise when earnings management risk is higher, resulting in higher audit fees.

In this context, we formulated the following research hypothesis:

H6: There is a positive association between earnings management and external audit fees. 


\section{Methodology}

\section{Variables}

Since the purpose of this study is to analyze the factors that influence external audit fees, the dependent variable to consider is the amount of audit fees (FEE). The introduction of a dichotomous variable in order to control the country made it possible to verify that the factors in question influence in a different way the audit fees of listed companies in Portugal and Spain. Thus, it became necessary to separate the study into two models, so we consider as dependent variables, respectively for Portugal and Spain:

- External audit fees for listed companies in Portugal (FEEPORT): correspond to the natural logarithm of the external audit fees for companies listed on the Euronext Lisbon Stock Exchange;

- External audit fees for listed companies in Spain (FEESPAIN): correspond to the natural logarithm of the external audit fees for companies listed on the Valencia, Madrid, Bilbao and Barcelona Stock Exchange.

Regarding the independent variables, these are the ones that allow us to test the six research hypotheses formulated in the previous section.

Several measures have been used to evaluate the size (SIZE) of the audited company, including turnover (Chan, Ezzamel \& Gwilliam, 1993), total current assets (Gerrard et al., 1994) and the number of employees (Naser \& Nuseibeh, 2007). However, in general, the logarithm of the client's total assets has been recognized in the literature as the measure that best describes the size of the audited company (Thi \& Hong, 2017; Joshi \& AL-Bastaki, 2000; Palmrose, 1986; Simunic, 1980; Urhoghide \& Izedonmi, 2015; among others). So, we are going to use this approach.

When it comes to the complexity (COMPL), the literature has resorted to various measures, including the number of different client's locations (Palmrose, 1986), foreign operations (Joshi \& AL-Bastaki, 2000), the number of business segments (Carcello et al., 2002). However, the most commonly used measures are the number of subsidiaries and the ratio between the number of foreign subsidiaries and the total number of subsidiaries of the audited company (Carcello et al., 2002; Gul et al. 2003; Thi \& Hong, 2017; Simunic, 1980). In this context, companies with a high number of subsidiaries require a greater effort by the auditor in order to verify and validate transactions and operations that may exist in large quantity. Because of this, we chose to measure this variable through the logarithm of the audited companies' number of subsidiaries as André et al. (2016). 
It is also important to understand if companies that control the market for audit services, the so-called big four, charge or not higher audit fees. Following several authors (Campa, 2013; Kimeli, 2016; UlHaq \& Leghari, 2015), we considered a dichotomous variable that determines whether the company is, or not, audited by a big four (BIG4). So, the BIG4 variable takes the value 1 if the firm is audited by a big four, and 0 otherwise.

Concerning the risk (RISK), this has been measured in many ways by the authors. The literature has used debt ratios, such as total liabilities to shareholders' equity (Karim \& Hasan, 2012; Thinggaard \& Kiertzner, 2008) and total liabilities to total assets (Naser \& Nuseibeh, 2007), liquidity ratios, including the quick ratio, calculated by total current assets less total inventories divided by current liabilities (Al-Harshani, 2008; André et al., 2016; Bills, Lisic and Seidel, 2017; Fleischer \& Goettsche, 2012), and the losses of previous years (Fuentes \& Pucheta-Martínez, 2009; Pong \& Whittington, 1994). In this study we chose the quick ratio.

Following the literature, we measured non-audit fees (NAF) by the logarithm of the total amount of other services provided by audit firms (Caneghem, 2010; Mayoral \& Segura, 2007; Simunic 1980; Thinggaard \& Kiertzner, 2008).

Earnings Management (EM) was measured by discretionary accruals (Alali, 2011; Gu $\& \mathrm{Hu}, 2015$; Gul et al., 2003). We calculated discretionary accruals according to the model of Dechow, Sloan and Sweeney (1995) that adjusted and make more efficient the model of Jones (1991). According to these models, total accruals include discretionary accruals (also called abnormal or unusual accruals) and non-discretionary accruals that are normal accruals:

Total Accruals $(\mathrm{TA})=$ Discretionary accruals $(\mathrm{DA})+$ Non-Discretionary accruals $(\mathrm{NDA})=\mathrm{DA}=\mathrm{TA}-\mathrm{NDA}$

According to the model of Dechow et al. (1995), non-discretionary accruals are calculated as follows:

$\mathrm{NDA}_{t}=\alpha_{1}\left(1 / \mathrm{A}_{\mathrm{t}-1}\right)+\alpha_{2}\left(\Delta \mathrm{REV}_{\mathrm{t}} / \mathrm{A}_{\mathrm{t}-1}-\Delta \mathrm{REC}_{\mathrm{t}} / \mathrm{A}_{\mathrm{t}-1}\right)+\alpha_{3}\left(\mathrm{PPE}_{\mathrm{t}} / \mathrm{A}_{\mathrm{t}-1}\right)\left(\Delta \mathrm{PPE}_{\mathrm{t}} / \mathrm{A}_{\mathrm{t}-1}\right)+v_{\mathrm{t}}$

Where:

$\begin{array}{lll}\triangle \mathrm{REV}_{\mathrm{t}} & = & \text { Revenues in year } \mathrm{t} \text { less revenues in year } \mathrm{t}-1 ; \\ \triangle \mathrm{REC}_{\mathrm{t}} & = & \text { Receivables in year } \mathrm{t} \text { less net receivables in year } \mathrm{t}-1 ; \\ \mathrm{PPE}_{\mathrm{t}} & = & \text { Gross property plant and equipment in year } \mathrm{t} ; \\ \mathrm{A}_{\mathrm{t}-1} & = & \text { Total assets in year } \mathrm{t}-1 ; \\ \alpha_{1}, \alpha_{2}, \alpha_{3} & = & \text { Firm-specific parameters. }\end{array}$


According to Jones (1991), the parameters $\alpha_{1}, \alpha_{2}, \mathrm{e} \alpha_{3}$ are usually estimated by the ordinary least square (OLS), using the following model:

$$
\mathrm{TA}_{\mathrm{t}}=\mathrm{a}_{1}\left(1 / \mathrm{A}_{\mathrm{t}-1}\right)+\mathrm{a}_{2}\left(\Delta \mathrm{REV}_{\mathrm{t}} / \mathrm{A}_{\mathrm{t}-1}\right)+\mathrm{a}_{3}\left(\Delta P \mathrm{PE}_{\mathrm{t}} / \mathrm{A}_{\mathrm{t}-1}\right)
$$

As for total accruals, these were calculated according to the following formula, indicated by Dechow et al. (1995).

$$
\mathrm{TAt}=(\Delta \mathrm{CAt}-\Delta \mathrm{CL} \mathrm{t}-\Delta \operatorname{cash} \mathrm{t}+\Delta \mathrm{STD} \mathrm{t}-\text { Dept }) / \mathrm{At}-1
$$

Where:

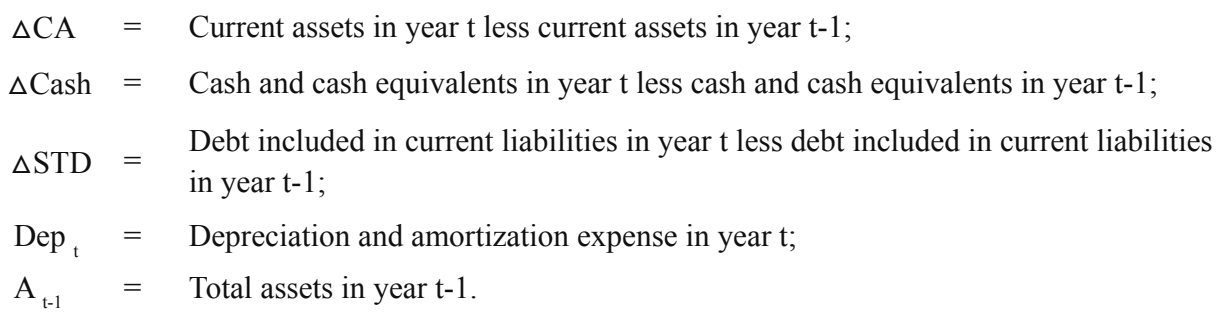

Finally, it is important to address audit firm and audit partner rotation. Bedard and Johnstone (2010), in the U.S.A, found that in the rotation year of the audit partner there is an increased effort deposited in the audit planning so that the auditor can get the client's business knowledge, however this cost doesn't pass to the client. Litt, Sharma, Simpson, and Tanyi (2014) have also verified, in the U.S.A, that the quality of financial reports decreases with the audit partner rotation. On the other hand, as audit partner rotation is required both in Portugal and in Spain it is important to control this requirement. In Portugal, according to the Statute of Statutory Auditors, audit partner is mandatory for public interest entities after seven years (Decree-law 140/2015). In Spain, according to Law 12/2010, the public interest entities or companies that have a turnover of more than 50 million euros will also be required to change the audit partner after seven years. However, Law 22/2015 changed this requirement to 5 years. For this reason, we tested in our sample the significance of a dichotomous variable that indicated, for each year of our study, whether the partner in charge of the auditing company changed. The results showed that, either for Portugal and Spain, the relation between audit partner rotation and audit fees is negative but not significant for our analysis period.

Although there is no obligation in Portugal and Spain, in the period under analysis, for the audit firm rotation, this obligation was established for a maximum of 9 years in Portugal 
(Decree-Law 140/2015) and 10 years in Spain (Law 22/2015). The literature has shown that when there is a change in the audit firm, audit fees change significantly. For example, Corbella, Florio, Giotti, and Mastrolia (2015), through a study in Italy, where audit firm rotation is mandatory, have verified that audit fees decrease with audit firm rotation. However, this decrease only occurs in the big four, since for non-big four firms audit fees remain unchanged. Similarly, Bills et. al (2017) also found, through a study in U.S.A, that audited companies pay lower fees when the audit firm is performing its duties in its first three years. Therefore, we have decided to use the influence that audit firm rotation has on audit fees in our model, as an alternative to the audit partner rotation. We used the variable AR as a control variable that is dichotomous, assuming the value 1 when it is verified that there was rotation of the audit firm for each of the years of study (2013, 2014 and 2015) and zero, otherwise. Considering the insufficiency of studies in this area, it is difficult to define, a priori, the expected relationship between audit firm rotation (AR) and audit fees.

Table 1 summarizes the variables, the measures and the expected effect.

Table 1

Variables's description

\begin{tabular}{|c|c|c|}
\hline Variables & Measures & $\begin{array}{l}\text { Expected } \\
\text { Effect }\end{array}$ \\
\hline FEEPORT & The natural logarithm of the external audit fee in Portugal & N/A \\
\hline FEESPAIN & The natural logarithm of the external audit fee in Spain & N/A \\
\hline SIZE & The natural logarithm of the client's total assets & + \\
\hline COMPL & The natural logarithm of the number of subsidiaries of the client & + \\
\hline BIG4 & $\begin{array}{l}\text { A dummy variable, equals to } 1 \text { if the auditor is a big four firm, and to } 0 \\
\text { if otherwise }\end{array}$ & + \\
\hline RISK & Liquidity ratio: (Current assets - Inventories) / Current liabilities & $-{ }^{2}$ \\
\hline NAF & $\begin{array}{l}\text { The natural logarithm of other services charged by the audit firm } \\
\text { (non-audit fees) }\end{array}$ & $?$ \\
\hline EM & Discretionary accruals measured according with Dechow et al.(1995) & + \\
\hline AR & $\begin{array}{l}\text { A dummy variable, equals to } 1 \text { if there is audit firm rotation in the period } \\
\text { under analysis, and to } 0 \text { otherwise }\end{array}$ & $?$ \\
\hline
\end{tabular}

Source: Own Elaboration

${ }^{2}$ The risk is measured by the quick ratio. It is therefore expected a negative association between this ratio and audit fees because the smaller the liquidity the higher the risk and, consequently, the audit fees. 
Model

To perform an analysis of the determinants of audit fees in Portugal and Spain, we tested our research hypotheses using the ordinary least squares (OLS) through Gretl program. The research model tested is the following:

$$
\mathrm{FEE}=\beta_{0}+\beta_{1} \mathrm{SIZE}+\beta_{2} \mathrm{COMPL}+\beta_{3} \mathrm{BIG} 4+\beta_{4} \mathrm{RISK}+\beta_{5} \mathrm{NAF}+\beta_{6} \mathrm{EM}+\beta_{7} \mathrm{AR}+\boldsymbol{\epsilon}
$$

Where FEE are the external audit fees for Portugal (FEEPORT) and Spain (FEESPAIN) and $\varepsilon$ is the error term.

\section{Sample}

In order to apply the regression model to analyze the factors that affect audit fees in Iberian Peninsula, we collected data from annual financial reports of the companies listed on the four Spanish Stock Exchanges (Valencia, Madrid, Bilbao and Barcelona) and on the Portuguese Stock Exchange (Euronext Lisbon) for the years 2013, 2014 and 2015. We chose this period because 2013 is already 8 years after the liberalization of fees in Portugal and 2015 is before the effects of the Community Directive.

The financial reports were obtained from the official websites of the Securities Market Commission of Portugal $\left(\mathrm{CMVM}^{3}\right)$ and Spain $\left(\mathrm{CNMV}^{4}\right)$.

From the initial sample of the listed companies we excluded the ones which we couldn't obtain the necessary data to test the formulated hypotheses and the companies that were not listed on the stock exchange during 2 years of the period under review. We also excluded companies providing financial services, since these companies have very specific characteristics and a degree of financial leverage that can bias the results (Fuentes \& Pucheta-Martínez, 2009). The final sample is a total of 143 companies, and among these 39 are Portuguese and 104 Spanish, as shown in table 2. It is important to point out that despite the small sample size, especially in the Portuguese case, it translates, respectively for Portugal and Spain, 76\% and $59 \%$ of the total companies and $85 \%$ and $68 \%$ of the non-financial ones.

\footnotetext{
${ }^{3}$ Comissão do Mercado de Valores Mobiliários

${ }^{4}$ Comisión Nacional del Mercado de Valores
} 
Table 2

Description of the sample

\begin{tabular}{lll}
\hline Companies with Securities Exchange: & Portugal & Spain \\
\hline Initial Sample: & 51 & 175 \\
Filters: & \\
Financial services & -5 & -23 \\
Insufficiency of data & -7 & -34 \\
Companies that are not listed on the stock exchange during 2 years of the period & 0 & -14 \\
under review & & 104 \\
Final Sample & 39 & \\
Total Sample & 143 & \\
\hline
\end{tabular}

Source: Own Elaboration

\section{Presentation and discussion of results}

Descriptive statistics: listed companies in Portugal

Table 3 presents, by sector, the number of companies, total audit fees and total assets of the companies of Portuguese sample for the period 2013 to 2015.

Table 3

Classification of companies listed on the Portuguese Stock Exchange by sector

\begin{tabular}{llcl}
\hline Sector & $\begin{array}{l}\text { Number of } \\
\text { companies }\end{array}$ & $\begin{array}{l}\text { Total External audit } \\
\text { fees }(€)\end{array}$ & Total assets $(€)$ \\
\hline $\begin{array}{l}\text { Agriculture, fishing, livestock, forestry, } \\
\text { mining, hunting }\end{array}$ & 0 & \multicolumn{1}{l}{} & - \\
$\begin{array}{l}\text { Industry, construction, electricity, gas and } \\
\text { water supply }\end{array}$ & 7 & $1174127.00 €$ & $68564872615.58 €$ \\
Trade and services & 32 & $6435460.44 €$ & $88439913414.05 €$ \\
Total & 39 & $7609587.44 €$ & $157004786029.63 €$ \\
\hline
\end{tabular}

Source: Own Elaboration

Most of the companies are dedicated to the third sector (trade and services) and the remaining companies belongs to the secondary sector (industry, construction, electricity, gas 
and water supply). During the analysis period of the present study, the listed companies in Portugal spent a total of 7610 million euros in external audit fees and reported a total assets amount of 157005 billion euros.

The descriptive statistics for the Portuguese model are reported in table 4 .

Table 4

Descriptive statistics for companies listed on the Portuguese Stock Exchange

\begin{tabular}{llllll}
\hline Variable & Mean & Median & Minimum & Maximum & Standard Deviation (SD) \\
\hline FEEPORT & 10.46 & 10.55 & 6.91 & 14.02 & 1.14 \\
SIZE & 19.74 & 19.52 & 16.59 & 23.83 & 1.50 \\
COMPL & 2.62 & 2.48 & 0.00 & 6.02 & 1.64 \\
BIG4 & 0.82 & 1.00 & 0.00 & 1.00 & 0.39 \\
RISK & 3.09 & 0.60 & 0.02 & 97.82 & 12.26 \\
NAF & 5.11 & 7.31 & 0.00 & 13.31 & 5.04 \\
EM & 0.01 & 0.00 & -0.63 & 0.72 & 0.14 \\
AR & 0.08 & 0.00 & 0.00 & 1.00 & 0.27 \\
\hline
\end{tabular}

Source: Own Elaboration

The COMPL variable is the logarithm of the number of subsidiaries of the audited company whose absolute value range between 0 and 411 subsidiaries, and there is a greater concentration of companies that have 1 to 20 subsidiaries. The BIG4 variable shows that the market of audit services for Portugal is dominated by the big four. The RISK variable indicates that, on average, the quick ratio of these companies is reasonable (3.09). Regarding the variable AR, only $8 \%$ of the companies have made this change between 2013 to 2015 . Table 5 also shows that EM is the variable that has a lower dispersion $(\mathrm{SD}=0.14)$ and RISK is the variable that has a greater dispersion of data $(\mathrm{SD}=12.26)$.

\section{Descriptive statistics: listed companies in Spain}

The business classification of the listed companies in Spain was also divided by sector (table 5). 


\section{A. S. Valente Cunha Silva, et al. / Contaduría y Administración 65(4), 2020, 1-24}

http://dx.doi.org/10.22201/fca.24488410e.2020.2039

Table 5

Classification of companies listed on the Spanish Stock Exchange by sector

\begin{tabular}{llll}
\hline Sector & Number of companies & External audit fees & Total assets \\
\hline $\begin{array}{l}\text { Agriculture, fishing, livestock, } \\
\text { forestry, mining, hunting }\end{array}$ & 2 & $324322.16 €$ & $1303427374.06 €$ \\
$\begin{array}{l}\text { Industry, construction, electricity, } \\
\text { gas and water supply }\end{array}$ & 36 & $25947049.06 €$ & $210812139974.27 €$ \\
$\begin{array}{l}\text { Trade and services } \\
\text { Total }\end{array}$ & 66 & $62831915.28 €$ & $831239229150.41 €$ \\
& 104 & $89103286.50 €$ & $1043354796498.74 €$
\end{tabular}

Source: Own Elaboration

As it can be observed in table 5, only 2 companies belong to the primary sector, 36 to the secondary sector and most of the companies belong to the tertiary sector. During the years of 2013, 2014 and 2015, the companies listed on the Spanish Stock Exchange spent 89103 million euros in external audit fees and reported a total asset amount of 1043 billion euros.

Descriptive statistics for the Spanish model are presented in table 6.

Table 6

Descriptive statistics for companies listed on the Spanish Stock Exchange

\begin{tabular}{llllll}
\hline Variables & Mean & Median & Minimum & Maximum & Standard Deviation \\
\hline FEESPAIN & 11.52 & 11.46 & 7.75 & 15.52 & 1.40 \\
SIZE & 19.91 & 19.97 & 11.77 & 25.18 & 2.24 \\
COMPL & 3.12 & 2.86 & 0.00 & 7.14 & 1.59 \\
BIG4 & 0.88 & 1.00 & 0.00 & 1.00 & 0.32 \\
RISK & 1.98 & 0.89 & 0.00 & 60.14 & 5.38 \\
NAF & 7.98 & 10.52 & 0.00 & 14.81 & 5.31 \\
EM & -0.68 & -0.06 & -20.86 & 7.26 & 2.73 \\
AR & 0.13 & 0.00 & 0.00 & 1.00 & 0.34 \\
\hline
\end{tabular}

Source: Own Elaboration

The descriptive analysis allows us to verify that the COMPL variable corresponds to the logarithm of the audited company number of subsidiaries that in absolute terms ranges between 0 and 1 142. By analyzing the BIG4 variable we concluded that $88 \%$ of the companies listed on the Spanish Stock Exchange are audited by big four firms. This means that, in Spain, the big four have a strong domain in the audit market for listed companies. In turn, the RISK 
variable indicates that the quick ratio of these companies is reasonable (1.98). Regarding the variable AR, the average indicates that only $13 \%$ of the companies changed the audit firm, while $87 \%$ remained with the same audit firm. Overall, these results indicate a low rotation of the audit partner over the three years analyzed. It can also be verified, through table 6 , that the BIG4 variable is the one that has a lower data dispersion $(\mathrm{SD}=0.32)$ and that the RISK variable is the one that has a higher data dispersion $(\mathrm{SD}=5.38)$.

\section{Regression analysis results: listed companies in Portugal}

The correlation matrix of the independent and control variables (table 7) shows that the strongest correlation is between COMPL and SIZE variables, which corresponds to 0. 45. The collinearity test does not reveal, however, problems of this type. We also performed tests on heteroscedasticity (white's test) and on the residual's normality that showed no concern with respect to the dispersion of the data and the error distribution.

Table 7

Correlation matrix for listed companies in Portugal

\begin{tabular}{|c|c|c|c|c|c|c|c|}
\hline & SIZE & COMPL & BIG4 & RISK & NAF & EM & $\mathrm{AR}$ \\
\hline SIZE & 1 & 0.45 & 0.30 & 0.08 & 0.19 & -0.03 & 0.06 \\
\hline COMPL & & 1 & 0.05 & 0.11 & -0.27 & 0.07 & -0.06 \\
\hline BIG4 & & & 1 & 0.08 & 0.30 & 0.10 & -0.03 \\
\hline RISK & & & & 1 & 0.07 & 0.19 & -0.04 \\
\hline NAF & & & & & 1 & -0.05 & -0.01 \\
\hline EM & & & & & & 1 & 0 \\
\hline AR & & & & & & & 1 \\
\hline
\end{tabular}

Source: Own Elaboration

Table 8 shows the results obtained for companies listed on the Portuguese stock exchange using the pooled OLS model, as it was verified to be more adequate than the fixed effects model (FEM) and the random effects model (REM). We run the F-statistic and the Hausman test in order to choose the most appropriate model among the pooled OLS, the FEM and the REM. We reject the Hausman test and do not reject the F-statistic, so, the pooled OLS is the best model, and we will analyze the respective results. In addition, the adjusted $\mathrm{R}^{2}$ obtained with the pooled OLS model is higher than the other models mentioned, which means that this model is the most explanatory of the external audit fees. 
Table 8

\begin{tabular}{|c|c|c|c|c|}
\hline Variables & Coefficient & T-statistic & $\mathrm{P}$ value & \\
\hline CONST & 3.43 & 2.49 & $0.02 * *$ & \\
\hline SIZE & 0.37 & 4.76 & $0.00 * * *$ & \\
\hline COMPL & -0.08 & -1.24 & 0.22 & \\
\hline BIG4 & -0.41 & -1.52 & 0.13 & \\
\hline RISK & -0.00 & 0.37 & 0.71 & \\
\hline NAF & 0.04 & 1.64 & 0.10 & \\
\hline EM & -0.56 & -0.75 & 0.46 & \\
\hline AR & -0.33 & 0.93 & 0.35 & \\
\hline Mean dependent variable: 10.47 & & & & 10.47 \\
\hline S.D. dependent variable: 1.15 & & & & 1.15 \\
\hline Sum squared residuals: 112.54 & & & & 112.54 \\
\hline S.E. of regression : 1.02 & & & & 1.02 \\
\hline Adjusted R-squared (R2): 0.21 & & & & .21 \\
\hline F (7. 108): 5.26 & & & & 5.26 \\
\hline P Value (F): 0.00 & & & & 0.00 \\
\hline
\end{tabular}

Results for listed companies in Portugal.

*** Significant at $p<0.01$

**Significant at $0.01<p<0.05$

*Significant at $0.05<p<0.10$.

Source: Own Elaboration

Additional analysis and robustness tests: companies listed in Portugal

In order to validate the results obtained, we performed robustness tests, considering different ways of measuring risk. Thus, as an alternative to the quick ratio, we considered as a proxy for risk the debt ratio, calculated by dividing total liabilities by equity, and total liabilities divided by total assets. Additionally, we consider the financial autonomy ratio, calculated by dividing the equity by total assets.

The results obtained are similar, so the conclusions obtained previously remain unchanged.

Regression analysis results: companies listed in Spain

The correlation matrix of independent and control variables (table 9) reports that the strongest correlation occurs for SIZE and COMPL variables, with a correlation of 0.67. However, it was performed a collinearity test and the results did not reveal any problem of this type. The 
heteroscedasticity test (White's test) and the residual's normality test revealed that there is a strong dispersion of the data and that the error has a normal distribution.

Table 9

Correlation matrix for listed companies in Spain

\begin{tabular}{llllllll}
\hline VARIABLES & SIZE & COMPL & BIG4 & RISK & NAF & EM & AR \\
\hline SIZE & 1.00 & 0.67 & 0.38 & -0.32 & 0.45 & -0.17 & -0.16 \\
COMPL & & 1.00 & 0.27 & -0.08 & 0.47 & -0.11 & -0.15 \\
BIG4 & & & 1.00 & -0.04 & 0.47 & -0.11 & -0.07 \\
RISK & & & & 1.00 & -0.16 & 0.00 & 0.05 \\
NAF & & & & & 1.00 & -0.06 & -0.18 \\
EM & & & & & & 1.00 & 0.05 \\
AR & & & & & & & 1.00 \\
\hline
\end{tabular}

Source: Own Elaboration

Table 10 sows the results obtained for the Spanish listed companies through the use of Pooled OLS for the same reasons presented for the Portuguese model.

Table 10

Results for listed companies in Spain

\begin{tabular}{llll}
\hline Variables & Coefficient & T-statistic & P value \\
\hline CONST & 3.80 & 7.26 & $0.00^{* * *}$ \\
SIZE & 0.34 & 10.92 & $0.00 * * *$ \\
COMPL & 0.17 & 3.83 & $0.00 * * *$ \\
BIG4 & 0.71 & 3.96 & $0.00 * * *$ \\
RISK & -0.03 & -3.35 & $0.00 * * *$ \\
NAF & -0.01 & -0.87 & 0.38 \\
EM & -0.03 & -1.66 & $0.10^{*}$ \\
AR & -0.29 & -1.99 & $0.04 * *$ \\
Mean dependent variable: & & & 11.52 \\
S.D. dependent variable: & & & 1.40 \\
Sum squared residuals: & & & 219.01 \\
S.E. of regression: & & & 0.86 \\
Adjusted R-squared $\left(\mathrm{R}^{2}\right):$ & & & 0.62 \\
F (7. 299): & & & 73.66 \\
P Value (F): & & & 0.00 \\
\hline
\end{tabular}

*** Significant at $p<0.01$

$* *$ Significant at $0.01<p<0.05$.

*Significant at $0.05<p<0.10$.

Source: Own Elaboration 
According to the results, the variables that explain external audit fees for Spain are the size (SIZE), complexity (COMPL) and risk (RISK) of the audited companies and when the audit firm is a big four (BIG4) as they present statistically significant values. The SIZE and COMPL variables are positively related to the external audit fees and corroborate the results of previous studies, such as Joshi and AL-Bastaki (2000), Kimeli (2016), Urhoghide and Izedonmi (2015), among others. According to these studies, the greater the size and complexity of the audited company, the higher the audit fees, possibly due to a greater effort and time spent by auditors.

Regarding the BIG4 variable, the results indicate that the big four firms charge higher audit fees, which corroborates the results of Fuentes and Pucheta-Martínez (2009).

As for the risk (RISK), this was measured by the quick ratio of the audited companies, so we have obtained a significant negative association between this ratio and external audit fees, reflecting a positive association between risk and audit price. In fact, the smaller the liquidity, the higher the level of financial risk, and consequently, the higher the amount of audit fees to be charged. Al-Harshani (2008) also found a negative association between audit fees and the liquidity of the audited company, stating that "when the audit client has a higher liquidity ratio, the expected cost of the audit risk becomes less, and thus, audit firms appear to be willing to charge lower audit fees"(p.692).

The results for non-audit fees (NAF) are consistent with Adelopo (2009) and Dunmore and Shao (2006), who did not find a significant association between both variables. Fuentes and Pucheta-Martínez (2009) developed a study in Spain on this matter and tried to prove that the audit and non-audit fees influence each other, but the results didn't corroborate it.

On the other hand, the results obtained for the earnings management variable (EM) are contrary to those obtained in the literature. Although the literature has been poorly developed on this matter, Alali (2011) and Gul et al. (2003) showed a positive and significant relationship between earnings management, measured by discretionary accruals, and audit fees. Unlike these results, our results show that there is a negative association between earnings management and audit fees, but they are only significant at $10 \%$ level.

The audit firm rotation (AR) is positively related with audit fees, showing that the rotation of audit firm leads to a decreasing in audit fees. These results are in line with those obtained by Corbella et. al (2015).

Finally, the adjusted R2 indicates that the model explains $62 \%$ of the external audit fees. 


\section{Additional analysis and robustness tests: companies listed in Spain}

In order to test the results obtained, we also performed some tests of robustness for the Spanish sample. We also considered other ways of measuring risk, already mentioned above. As in the Portuguese sample, the results obtained are similar to those obtained previously, so that, in general, the conclusions remain. Regarding the type of industry, we also perform several types of robustness tests, using the Statistical Classification of Economic Activities in the European Community (NACE), which includes 21 different classifications. Several dichotomous variables were created that allowed us to control these economic activities. The tests of robustness to the type of industry were only performed for the Spanish sample since the Portuguese sample is very small.

Unlike to Kikhia (2015) which showed that manufacturing industries pay higher audit fees in Jordan, in Spain this type of industry does not have a significant effect on the amount of audit fees paid. On the other hand, electricity, gas, steam and air conditioning activities pay significantly higher audit fees, while construction and wholesale and retail activities, repair of motor vehicles and motorcycles pay significantly lower audit fees. However, these results are conditioned by the number of companies included there, since only 4, 8 and 7 companies belong to these economic nomenclatures. Real estate companies (14 companies) also pay significantly lower audit fees than the other companies

\section{Conclusion}

Audit fees have a strong influence on auditor's independence, because they represent an economic link between the auditor and the client and arise as one of the factors that may limit the auditor's professional judgment. Therefore, it is important to study the factors that influence the audit fees.

In this context, this study aimed to analyze audit fees for companies listed on the Spanish (Bilbao, Valencia, Barcelona and Madrid) and Portuguese (Euronext Lisbon) stock exchanges.

Comparing the Portuguese audit market with the Spanish one, it can be observed that $18 \%$ of the companies listed on the Portuguese stock exchange are audited by non-big four, while in Spain this share decreases to $12 \%$. The results indicate that the preeminence of the big four is bigger in Spain than in Portugal.

According to the results the determinants of audit fees in Portugal are different from those found for Spain, what mean that the economic environment of audit services is also different in both countries. In Portugal, the only variable considered capable of influencing the amount 
of audit fees was the size of the audited companies. These results indicated that in Portugal, despite the table setting minimum audit fees is not mandatory since 2005, auditors continue to be strongly influenced by it or for the base construction of this factor (the size of the audited company). On the other hand, in Spain, audit fees are mainly and positively affected by the size, complexity and audit risk. The bigger the size, complexity and risk of the audited company, the higher the audit fees. The big four firms also charge higher audit fees in Spain but not in Portugal. It was also found that, in Spain, companies that change audit firms pay lower fees in the year of rotation. Earnings management was also found to be statistically significant, although at a lower level, in the determination of audit fees.

This study provides a better understanding of the factors that influence auditing fees in two European countries. Contributing to verify that despite the commonalities of the countries under review there are differences in the factors influencing auditing fees.

The main limitation of this study is the small sample size, especially in the Portuguese sample, although this limitation results directly from the size of the Portuguese capital market, since all non-financial companies listed at least two years of the period under review were included.

Regarding future research, it would be interesting to analyze the association between audit fees and corporate governance measures. Another interesting research issue is the analysis of audit fees after the introduction of the new rules resulting from the application of European Directive.

\section{References}

Adelopo, I. (2009). Modelling issues in the relation between audit and non-audit fees. Journal of Applied Accounting Research, 10(2), 96-108. http://doi.org/10.1108/09675420910984664

Alali, F. (2011). Audit Fees and Discretionary Accruals: Compensation Structure Effect. Managerial Auditing Journal, 26(2), 90-113. http://doi.org/10.1108/02686901111094994

Al-Harshani, M. O. (2008). The pricing of audit services: evidence from Kuwait. Managerial Auditing Journal, 23(7), 685-696. https://doi.org/10.1108/02686900810890643

Al-Shammari, B., Al-Yaquot, A., \& Al-Hussaini, A. (2008). Determinants of audit fees in Kuwait. Journal of the Academy of Business and Economics, 8(1), 140.

André, P., Broye, G., Pong, C., \& Schatt, A. (2016). Are Joint Audits Associated with Higher Fees? European Accounting Review, 25(2), 245-274. https://doi.org/10.1080/09638180.2014.998016

Balsam, S. (1998). Discretionary Accounting Choices and CEO Compensation. Contemporary Accounting Research, 15(3), 229-252. http://doi.org/10.1111/j.1911-3846.1998.tb00558.x

Bedard, J. C., \& Johnstone, K. M. (2010). Audit partner tenure and audit planning and pricing. Auditing: A Journal of Practice and Theory, 29(2), 45-70. http://doi.org/10.2308/aud.2010.29.2.45

Bills, K. L., Lisic, L. L., \& Seidel, T. A. (2017). Do CEO succession and succession planning affect stakeholders' perceptions of financial reporting risk? evidence from audit fees. Accounting Review, 92(4), 27-52. https://doi. org/10.2308/accr-51567 
Campa, D. (2013). Big 4 fee premium" and audit quality: latest evidence from UK listed companies. Managerial Auditing Journal, 28(8), 680-707. http://doi.org/10.1108/MAJ-11-2012-0784

Caneghem, T. Van. (2010). Audit pricing and the Big4 fee premium: evidence from Belgium. Managerial Auditing Journal, 25(2), 122-139. http://doi.org/10.1108/02686901011008945

Carcello, J. V., Hermanson, D. R., Neal, T. L., \& Riley, R. (2002). Board Characteristics and Audit Fees. Contemporary Accounting Research, 19(3), 365-384. http://doi.org/10.1506/CHWK-GMQ0-MLKE-K03V

Chan, P., Ezzamel, M., \& Gwilliam, D. (1993). Determinants of Audit Fees for Quoted UK Companies. Journal of Business Finance and Accounting, 20(6), 765-786. https://doi.org/10.1111/j.1468-5957.1993.tb00292.x

Collier, P., \& Gregory, A. (1996). Audit committee effectiveness and the audit fee. European Accounting Review, 5(2), 177-198. http://doi.org/10.1080/09638189600000012

Corbella, S., Florio, C., Gotti, G., \& Mastrolia, S. A. (2015). Audit firm rotation, audit fees and audit quality:The experience of Italian public companiesSilvano. "Journal of International Accounting, Auditing and Taxation," 25, 46-66. https://doi.org/10.1016/j.intaccaudtax.2015.10.003

Dechow, P. M., Sloan, R. G., \& Sweeney, A. P. (1995). Detecting Earnings Management. The Accounting Review, $70(2), 193-225$.

Decree-Law 140/2015 of 12 August of Assembleia da República. Diário da República:I série, No 174 (2015).

Decree - Law 224/2008 of 20th November of Assembleia da Républica, Diário da República: I série, No 226 (2008). Retrieved from https://dre.pt/.

Dunmore, P. V, \& Shao, Y. S. (2006). Audit and Non-Audit Fees: New Zealand Evidence. Pacific Accounting Review, 18(2), 32-46. http://doi.org/10.1108/01140580610732804

Felix, W. L. J., Gramling, A. A., \& Maletta, M. J. (2001). The Contribution of Internal Audit as a Determinant of External Audit Fees and Factors Influencing This Contribution. Journal of Accounting Research, 39(3), 513-534. http://doi.org/10.1111/1475-679X.00026

Fleischer, R., \& Goettsche, M. (2012). Size effects and audit pricing: Evidence from Germany. Journal of International Accounting, Auditing and Taxation, 21(2), 156-168. http://doi.org/10.1016/j.intaccaudtax.2012.07.005

Fuentes, C. De, \& Pucheta-Martínez, M. C. (2009). Auditor independence, joint determination of audit and non-audit fees and the incidence of qualified audit reports. Revista Latinoamericana de Administración, 43(2. ${ }^{\circ}$ semestre), 63-92.

Gerrard, I., Houghton, K., \& Woodliff, D. (1994). Audit Fees: The Effects of Auditee, Auditor and Industry Differences. Managerial Auditing Journal, 9(7), 3-11. http://doi.org/10.1108/02686909410067534

Gonthier-Besacier, N., \& Schatt, A. (2007). Determinants of audit fees for French quoted firm. Managerial Auditing Journal, 22(2), 139-160. http://doi.org/10.1108/02686900710718654

Gu, J., \& Hu, D. (2015). Audit Fees, Earnings Management, and Litigation Risk: Evidence from Japanese Firms Cross-Listed on U.S. Markets. Academy of Accounting and Financial Studies Journal, 19(3), 125-139.

Gul, F. a, Chen, C. J. P., \& Tsui, J. S. L. (2003). Discretionary Accounting Accruals, Managers' Incentives, and Audit Fees. Contemporary Accounting Research, 20(3), 441-464. http://doi.org/10.1506/686E-NF2J-73X6-G540

Hassan, Y. M., \& Naser, K. (2013). Determinants of Audit Fees: Evidence from an Emerging Economy. International Business Research, 6(8), 13-25. http://doi.org/10.5539/ibr.v6n8p13

Heninger, W. G. (2001). The association between auditor litigation and abnormal accruals. The Accounting Review, 76(1), 111-126. http://doi.org/10.2308/accr.2001.76.1.111

Ho, S., \& Hutchinson, M. (2010). Internal audit department characteristics/activities and audit fees: Some evidence from Hong Kong firms. Journal of International Accounting, Auditing and Taxation, 19(2), 121-136. http:// doi.org/10.1016/j.intaccaudtax.2010.07.004

ISA 315. (2012). International Standard on Auditing 315: Identifying and Assurance The Risks of Material Misstatement Through Understanding the Entity and its Environment. In Handbook of international quality control, auditing, review, other assurance, and related services pronouncements (Vol. 1, pp. 265-314). New York: International Federation of Accountants

Jones, J. J. (1991). Earnings Management During Import Relief Investigations. Journal of Accounting Research, 29(2), 193-228. http://doi.org/10.2307/2491047 


\section{A. S. Valente Cunha Silva, et al. / Contaduría y Administración 65(4), 2020, 1-24}

http://dx.doi.org/10.22201/fca.24488410e.2020.2039

Joshi, P. L., \& AL-Bastaki, H. (2000). Determinants of Audit Fees: Evidence from the Companies Listed in Bahrain. International Journal of Auditing, 4(2), 129-138. http://doi.org/10.1111/1099-1123.00308

Kaplan, R. S. (1985). Comments on Paul Healy: Evidence on the Effect of Bonus Schemes on Accounting Procedure and Accrual Decisions. Journal of Accounting and Economics, 7(1-3), 109-113. http://doi. org/10.1016/0165-4101(85)90030-8

Karim, A. W., \& Hasan. (2012). The market for audit services in Bangladesh. Journal of Accounting in Emerging Economies, 2(1), 50-66.. http://doi.org/10.1108/20421161211196120

Kikhia, H. Y. (2015). Determinants of Audit Fees: Evidence from Jordan. Accounting and Business Research, 4(1), 42-53. http://doi.org/10.5430/afr.v4n1p42

Kimeli, E. K. (2016). Determinants of Audit Fees Pricing : Evidence from Nairobi Securities Exchange ( NSE ). International Journal of Research in Business Studies and Management, 3(1), 23-35.

Kreutzfeldt, R., \& Wallace, W. (1986). Error Characteristics in Audit Populations: Their Profile and Relation to Environmental Factors. Auditing: A Journal of Practice and Theory, 6(1), 20-43.

Krishnan, G. V. (2003). Audit quality and the pricing of discretionary accruals. Auditing, 22(1), 109-126. http:// doi.org/10.2308/aud.2003.22.1.109

Law 12/2010 of 1 st July of Auditoría de Cuentas, Boletín Oficial del Estado, No 159 (2010).

Law 22/2015 of 20th July of Auditoría de Cuentas, Boletín Oficial del Estado, No 173 (2015).

Litt, B., Sharma, D. S., Simpson, T., \& Tanyi, P. N. (2014). Audit partner rotation and financial reporting quality. Auditing: A Journal of Practice and Theory, 33(3), 59-86. http://doi.org/10.2308/ajpt-50753

Mayoral, J. M., \& Segura, A. S. (2007). Un estudio empírico de los honorarios del auditor. Cuadernos de Economía Y Dirección de La Empresa, 10(32), 81-109. http://doi.org/10.1016/S1138-5758(07)70092-0

Naser, K., \& Nuseibeh, R. (2007). Determinants of audit fees: empirical evidence from an emerging economy. International Journal of Commerce and Management, 17(3), 239-254. http://doi.org/10.1108/10569210710833635

Niemi, L. (2002). Do Firms Pay for Audit Risk? Evidence on Risk Premiums in Audit Fees after Direct Control for Audit Effort. International Journal of Auditing, 6(1), 37-51. http://doi.org/10.1111/j.1099-1123.2002.tb00004.x

Palmrose, Z.-V. (1986). Audit Fees and Auditor Size: Further Evidence. Journal of Accounting Research, 24(1), 97-110. http://doi.org/10.2307/2490806

Pong, C. M., \& Whittington, G. (1994). The Determinants of Audit Fees : Some Empirical Models. Journal of Business Finance and Accounting, 21(8), 1071-1095. http://doi.org/10.1111/j.1468-5957.1994.tb00365.x

Pratt, J., \& Stice, J. D. (1994). The Effects of Client Characteristics on Auditor Litigation Risk Judgments, Required Audit Evidence, and Recommended Audit Fees. The Accounting Review, 69(4), 639-656.

Sharma, D. S., \& Sidhu, J. (2001). Professionalism vs. commercialism: The association between nonaudit services (NAS) and audit independence. Journal of Business Finance \& Accounting, 28(5-6), 563-594. http://doi.org/10.1111/14685957.00386

Simunic, D. A. (1980). The Pricing of Audit Services: Theory and Evidence. Journal of Accounting Research, 18(1), 161. http://doi.org/10.2307/2490397

Suwaidan, M. S., \& Qasim, A. (2010). External auditors' reliance on internal auditors and its impact on audit fees. Managerial Auditing Journal, 25(6), 509-525. http://doi.org/10.1108/02686901011054845

Thi, N., \& Hong, P. (2017). The Determinants of Audit Fees for Companies in Vietnam. Journal of Economics and Development, 19(2), 68-88.

Thinggaard, F., \& Kiertzner, L. (2008). Determinants of Audit Fees: Evidence from a Small Capital Market with a Joint Audit Requirement. International Journal of Auditing, 12, 141-158. http://doi.org/10.1111/j.10991123.2008.00377.x

UlHaq, A., \& Leghari, M. K. (2015). Determinants of Audit Fee in Pakistan. Research Journal of Finance and Accounting, 6(9), 176-189.

Urhoghide, R. O., \& Izedonmi, F. O. . (2015). An Empirical Investigation of Audit Fee Determinants in Nigeria. International Journal of Business and Social Research, 5(8), 48-58. 